\title{
Asset Life Cycle Management in Finnish Water Utilities
}

\author{
Riikka P. Rajala, Jarmo J. Hukka \\ Civil Engineering Faculty of Business and Built Environment, Tampere University of Technology, Tampere, Finland \\ Email: riikka.rajala@tut.fi
}

How to cite this paper: Rajala, R.P. and Hukka, J.J. (2018) Asset Life Cycle Management in Finnish Water Utilities. Journal of Water Resource and Protection, 10, 587-595.

https://doi.org/10.4236/jwarp.2018.106033

Received: May 17, 2018

Accepted: June 25, 2018

Published: June 28, 2018

Copyright ( 2018 by authors and Scientific Research Publishing Inc. This work is licensed under the Creative Commons Attribution International License (CC BY 4.0).

http://creativecommons.org/licenses/by/4.0/

(c) (i) Open Access

\begin{abstract}
The aim of this paper is to improve the water industry asset life cycle management framework towards more resilient water services in Finland. This paper is based on a literature study and a web-based semi-structured thematic interview, in which the Finnish water utility managers identified the current status of their utilities' asset management. The water services professionals are extremely worried that, by and large, water and sewage networks are still deteriorating, although the networks are nowadays rehabilitated more systematically. The survey reveals that although most of the surveyed utilities have adopted several processes and sub-processes of asset management, and a few utilities are even using some asset management guides, as a whole a strategic approach to and a comprehensive framework for optimized management of physical assets are not practiced. Therefore the development and introduction of specific asset management guidelines should be considered. In order to support successful usage of the asset management framework, the basic concepts and principles of engineering asset management should be included in educational and professional development programs, in particular at the university level.
\end{abstract}

\section{Keywords}

Finnish Water Utilities, Aging Infrastructure, Asset Life Cycle Management Framework, Regulation and Enforcement

\section{Introduction}

Sustainable water infrastructure is critical to ensuring the sustainability of communities according to the United States Environmental Protection Agency [1]. The sustainability depends, however, on the practices on three levels that support each other (Figure 1): 


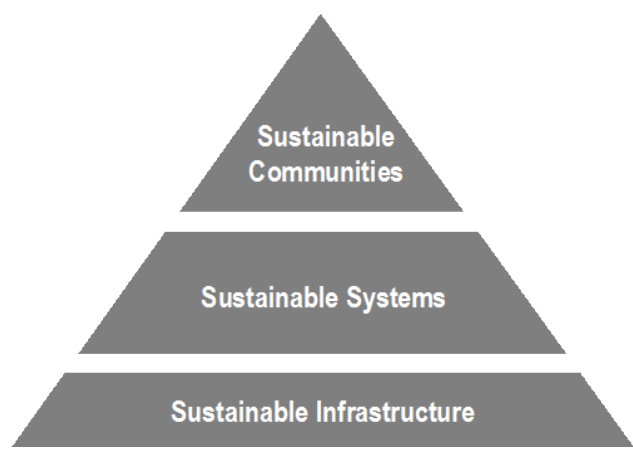

Figure 1. Sustainable communities [2].

1) Sustainable Water Infrastructure: Sustaining the collection and distribution systems, treatment plants and other infrastructure that collects, treats and delivers water-related services.

2) Sustainable Water Sector Systems: Sustaining all aspects of the utilities and systems that provide water-related services.

3) Sustainable Communities: Promoting the role of water services in furthering the broader goals of the community.

In Finland, the Water Services Act (119/2001, the amendment 681/2014) stipulates that the water services cover the conveyance, treatment and distribution of potable water for the community's use as well as the collection, treatment and disposal of wastewater [3] [4]. Therefore, as defined broadly, the concept of the water services includes the abstraction and processing of raw water, the distribution and supply of purified water for community use, and also the sewerage for collecting and conveying wastewater of the community, treatment of wastewater, and discharging the treated wastewater into the environment. The protection of raw water sources and environmental conservation related to the aforesaid activities can also be included in water services production.

\section{Water Services Undertakings in Finland}

There are approximately 1500 water services undertakings in Finland. The municipalities are the owners of 400 undertakings distributing 90 per cent of the total quantity of drinking water sold [5] [6]. Approximately 1100 user-owned water associations supply 10 per cent of the drinking water sold to approximately 13 per cent of the population [7].

The drinking water networks covered about $92 \%$ and the sewerage networks covered about $85 \%$ of the Finnish households in 2011. The length of the drinking water networks is about $100,000 \mathrm{~km}$ and the length of the sewerage networks (incl. stormwater pipelines) is about $50,000 \mathrm{~km}$. The length of the networks is constantly growing due to the expansion of the water services areas, and the introduction of separate sewer systems. The networks are considerable old, and their condition is not well known. The networks are also rapidly aging, but only a few water services undertakings have been able to increase their rehabilitation funds accordingly [8]. 
Although there are rather stringent judicial obligations with regard to covering the costs of maintaining, rehabilitating and replacing the water services fixed assets, the aging infrastructure-especially the decaying networks-was assessed to be the most significant challenge in the water services sector in the next 20 30 years [9]. The interviewed water utility experts, consultants, authorities, associations, researchers and educators pointed out that the state of networks was already truly alarming. They also revealed that the situation will become even worse if the rehabilitation and renewal activities are not increased considerably in the next few years.

Furthermore, a group of water sector professionals assessed the future challenges facing the water services in Finland in 2016. According to them, the investment gap of water services infrastructure is alarmingly large. The cost recovery is not implemented adequately enough. Therefore the responsible stakeholders should take proper actions to advocate and convince the municipal decision-makers to impose viable charges. This would also require development and introduction of the asset management systems and practices for the water services undertakings. In addition, the related judicial regulation and enforcement or voluntary measures should be introduced for the management of water industry assets in Finland [10].

When the state of the built environment was assessed in Finland in 2016-2017, the condition of water and wastewater infrastructure was rated a little over 7 by a group of Finnish water and wastewater experts on a scale from 4 (fail) to 10 (excellent). They pointed out that it is highly alarming that water and sewage networks as a whole are still decaying, although the networks are rehabilitated more systematically than earlier. Only less than ten per cent of the municipalities have comprehensive information, for example, about the condition of their water distribution network. In 2013, approximately twenty per cent of the municipalities had no knowledge at all of the condition of their water distribution system. More than 80 per cent of the municipalities have no cost estimates for rehabilitation requirements of their water services infrastructure. The experts recommended therefore, that the arrangements for introduction of the physical asset management framework should be taken care of in all municipalities [11].

\section{Asset Management}

The lifecycle functions of water industry asset management comprise of planning, asset selection, acquisition, operations, maintenance, repairing, upgrading and ultimate disposal or renewal of capital assets [12]. Vinnari (2006) defined the water undertakings' asset management as a business philosophy, the key component of which is an operations, maintenance, rehabilitation and replacement strategy based on customer service standards and economic objectives. According to her, the asset management is applied in practice, for example, to extend the lifecycle of the facilities and networks, to decrease the expenses without lowering the service level, and to secure that the water undertaking has 
enough funds to acquire, maintain, rehabilitate, upgrade and replace capital assets. She also gave an example representing a comprehensive asset management system (Table 1) [13].

By its nature, the production of the water services is extremely capital-intensive. According to the Finnish Water Utilities Association (2001) the water utility operating expenditures and capital costs which are not depending on water use, are normally about 80 - 90 per cent of the total costs. The networks are representing a major share, about 80 per cent, of the water utility's fixed assets. Because of the capital intensity the asset management system-one of the sustainable water sector systems (see: Figure 1)-should have a key role in the water services industry [14] [15].

The asset management in the water services sector was introduced more widely in the end of the 1980s, when the public regional water undertakings were privatized in England and Wales. Consequently, the economic regulatory authority for England and Wales, the Office of Water Services (OFWAT), started requiring long-term investment plans in order to define the permissible price level for the private water companies. At the same time, in Australia and in New Zealand the legislative changes concerning the public sector required the water utilities to operate on the basis of the commercial principles, although the utilities mainly remained under public ownership. In New Zealand, the preparation of the asset management plans is based on the legislation, whereas in Australia

Table 1. Components of Seattle Public Utilities (SPU) asset management system [13].

\begin{tabular}{|c|c|}
\hline Component & Implementation activity \\
\hline Define service levels & Annual customer surveys, stakeholder interviews \\
\hline Learn about risks & $\begin{array}{l}\text { Tracking and tagging of most critical assets by probability or } \\
\text { failure/consequence analysis; lower risks by rehabilitation, } \\
\text { operations and maintenance }\end{array}$ \\
\hline Focus on life cycle costs & $\begin{array}{l}\text { Assess life-cycle costs and benefits of each planned } \\
\text { project/investment }\end{array}$ \\
\hline Use triple bottom line & $\begin{array}{l}\text { Prioritize projects/investments based on societal, economic } \\
\text { and environmental impacts }\end{array}$ \\
\hline Optimize data and data systems & $\begin{array}{l}\text { Inventory of technical characteristics, age, location, } \\
\text { maintenance history, condition and current value of each asset } \\
\text { component }\end{array}$ \\
\hline $\begin{array}{l}\text { Create strategic asset } \\
\text { management plans }\end{array}$ & $\begin{array}{l}\text { Description of current condition of asset components, and } \\
\text { operations, maintenance and rehabilitation strategies; risk } \\
\text { management plans for operational and economic risks }\end{array}$ \\
\hline Clarify roles and responsibilities & $\begin{array}{l}\text { Define work team and individual responsibilities, } \\
\text { responsibility areas and decision-making authorities }\end{array}$ \\
\hline $\begin{array}{l}\text { Make large investment decisions } \\
\text { via asset management committee }\end{array}$ & $\begin{array}{l}\text { Meets once a week, analyses and finances large investments } \\
\text { (>EUR 200,000.00), ensures that decisions are based on } \\
\text { life-cycle cost and triple bottom line principles, approves } \\
\text { project plans, decides customer service and environmental } \\
\text { standards }\end{array}$ \\
\hline
\end{tabular}


the preparation practices change from one state to another, but are mainly associated with the water and wastewater price regulation [13] [16].

In Australia, being one of the pioneers in asset management, the water utilities have had an increasing focus on continuous development and improvement of their asset life cycle management practices over the last decade. In addition, the Water Services Association of Australia (WSAA) has developed the ISO 55001 Guidelines for the Water Industry as an initiative of the WSAA Asset Management Program [12].

In Finland, the Water Services Act (119/2001, the amendment 681/2014) stipulates, however, that the water service charges have to cover the water services undertaking's investments in acquisition and in repair of its capital asset, and all the costs in the long-term [3]. In addition, the Ministry of Agriculture (2015) urged that the capital outlays and the costs stipulated in the Act have to be understood widely [4]. The construction and extensions of the networks, or the procurement of the equipment, for example, must be considered the acquisition capital outlays. All the investments the undertaking makes, e.g., in rehabilitation, renewal and upgrading of the capital assets are considered the repair capital outlays.

The costs shall include all expenses directly related to the operations of the undertaking. They include both operating expenditures and capital costs. The costs may also cover environmental and resource costs in accordance with Article 9 of the European Union's Water Framework Directive. Gustafsson (2013) argued, however, that in Finland the most serious constraint related to the regulation of the water industry business operations is that actually the regulation of the water services charges does not belong to any authority's jurisdiction [17].

One specific feature of water services infrastructure is that the rehabilitation and renewal of the capital assets requires long-term commitment. Therefore all the stakeholders should be aware both of the actions, the capital outlays, and the costs involved. Because of the invisibility and the longevity of the capital assets, the Finnish municipal decision-makers do not necessarily pay enough attention to repair and renewal of the water services infrastructure. If the lifecycle of water services assets is shorter than planned, the renewal investments should be made earlier than expected. This would become costly to the citizens and businesses, and endanger the resilience of services.

In 2015, in order to assist the Finnish municipalities to manage better, more economically and equally the life cycle of their fixed assets, the Municipal Engineering Association of Finland (SKTY) has published a quick guide to the public infrastructure asset management [18]. The guide is mainly based on the International Infrastructure Management Manual (IIMM), which has been applied and complemented to better cope with the needs of the Finnish municipalities [19].

\section{Asset Management Survey}

The questionnaire was sent to 78 municipal water utilities in Finland during 
February-March 2017. Webropol Survey and Analysis tool was used to diagnose the replies. Altogether 26 utilities (33\%) replied. Most of the repliers (38\%) were municipal enterprises (Figure 2). Almost all (96\%) of them abstracted and distributed drinking water, and $77 \%$ of them were also responsible for wastewater management. The number of people served is shown in Table 2.

Interestingly enough, the survey reveals that none of the replied utilities have adopted the SFS-ISO 55000 Asset Management standard series for optimized management of their physical assets. Only five utilities are using other asset management guides in their business operations. Altogether nine (35\%) utilities carry out annual customer surveys or stakeholder interviews. Other utilities indicated that customer surveys or stakeholder interviews are implemented every second or third year or even less often. Three utilities are never doing the aforesaid surveys or interviews. The rest of the questions and the corresponding replies are given in Figure 3 and Figure 4. As shown in Figure 3 according to survey it is obvious that utilities participate in national benchmarking but only a few participate in international benchmarking. Utilities pay attention to reduce risks. About half of the utilities assess the life-cycle costs and benefits of each planned significant project or investment. As shown in Figure 4 majority of utilities prioritize significant investments based on societal, economic and environmental impacts.

Table 2. Number of people served by the surveyed utilities.

\begin{tabular}{ccc}
\hline Number of people served & Number of utilities & Per cent of utilities (\%) \\
\hline less than 1000 & - & - \\
$1000-5000$ & 3 & 12 \\
$5000-10,000$ & 5 & 38 \\
$10,000-50,000$ & 10 & 31 \\
$50,000-500,000$ & 8 & - \\
more than 500,000 & - &
\end{tabular}

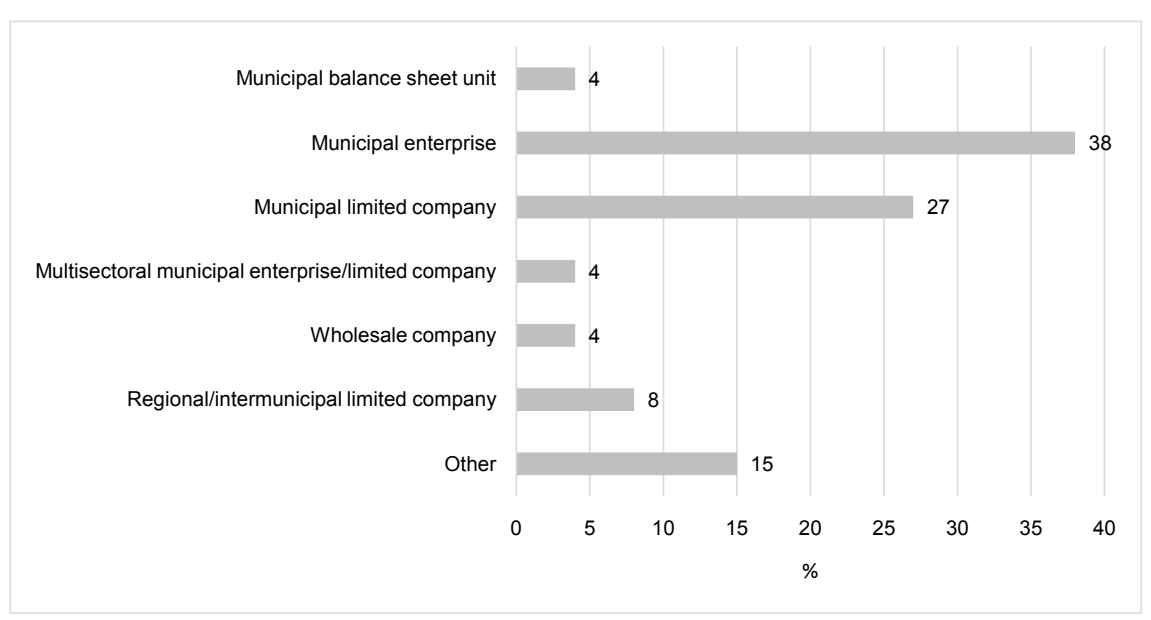

Figure 2. Percentage of surveyed utilities classified based on organizational model (\%). 


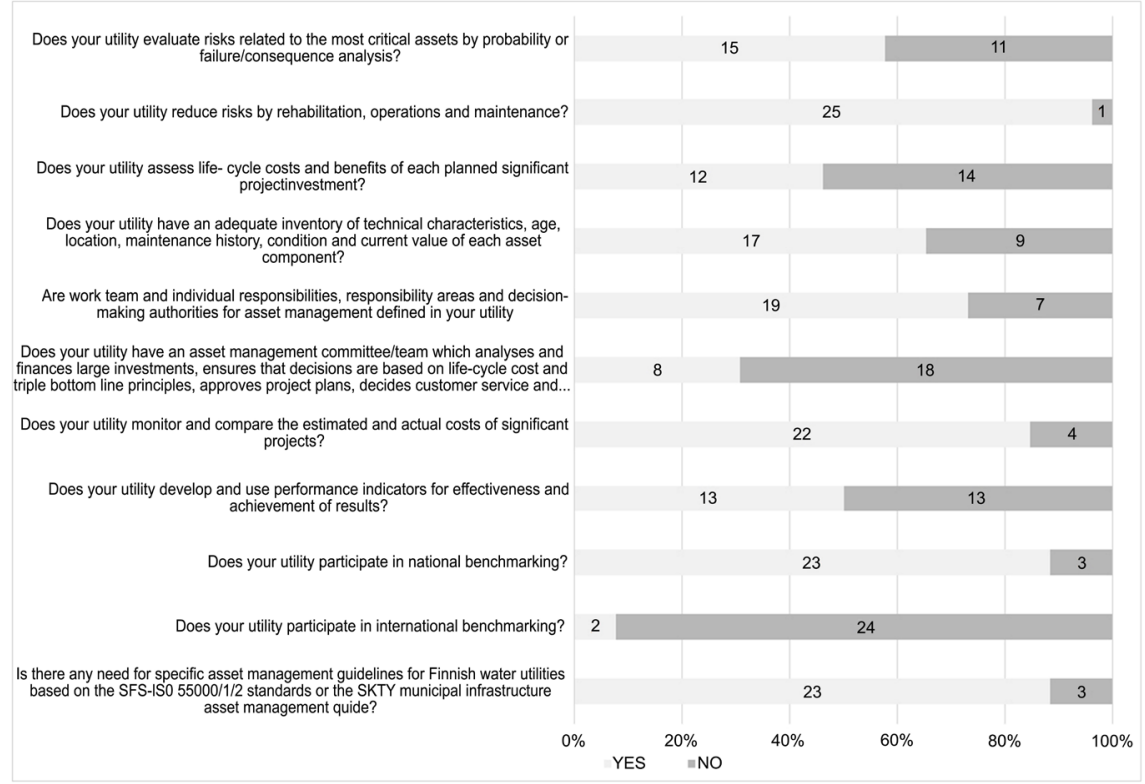

Figure 3. Survey questions and number of utilities replied (yes or no).

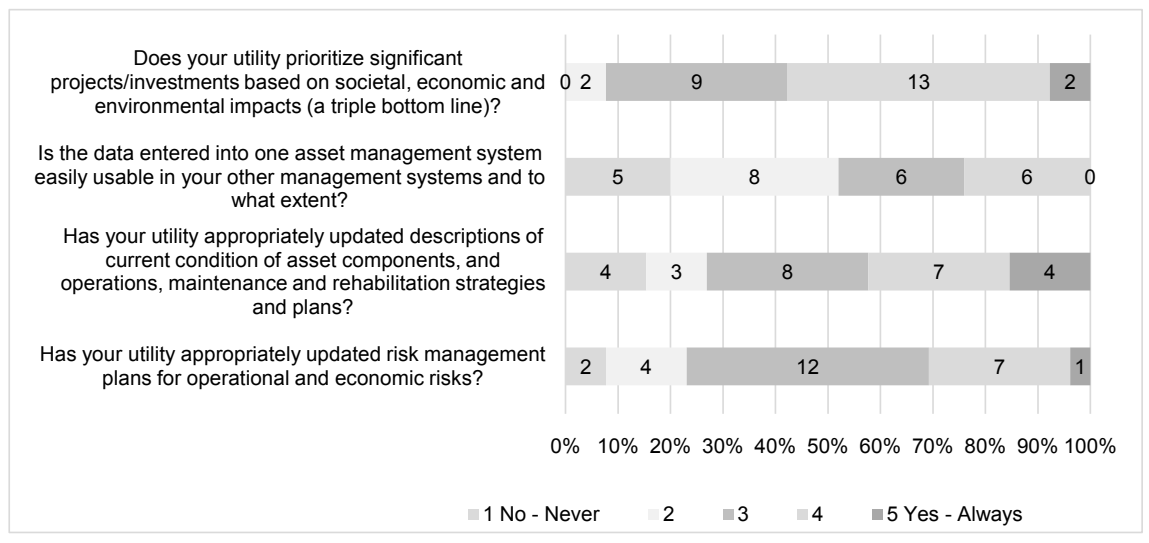

Figure 4. Replies classified based on the scale from 1 (no, never)-5 (yes, always).

\section{Conclusions}

The Finnish water services professionals predominantly agree that the biggest challenge in the water industry is aging and deteriorating water and wastewater infrastructure today and in the coming 20 - 30 years. The municipalities-by far owning the largest share of the water services infrastructure-have very limited knowledge of the current condition of their critical physical assets. The professionals have urged that a physical asset management framework, systems and practices as well as related judicial regulation and enforcement or voluntary measures must be introduced to improve the water industry asset management.

Our survey shows that although most of the surveyed utilities have in practice adopted several processes and sub-processes of asset management, and few utilities are using some asset management guides for their business operations, as a whole a strategic approach to and a comprehensive framework for optimized management of the physical assets are not practiced. Most of the surveyed utili- 
ties also stipulated that there is a need for specific asset management guidelines for the Finnish water utilities based on the SFS-ISO 55,000 Asset Management standards or on the municipal infrastructure asset management guide by the Municipal Engineering Association of Finland.

We therefore strongly recommend that the Association of Finnish Local and Regional Authorities and Finnish Water Utilities Association consider developing and introducing such asset management guidelines for the water services undertakings. The Ministry of Agriculture and Forestry should consider the formulation and introduction of more comprehensive rules and regulation, and an inclusive but lean enforcement for the water industry asset management. We also recommend, that in order to support the successful usage of the asset management framework to benefit and improve water industry business performance, the basic concepts and principles of engineering asset management are included in the relevant national educational and professional training programs, in particular at the university level.

\section{Acknowledgements}

We wish to thank the Academy of Finland for the financial support (Decision no. 288153). Our special thanks go to Dr. O. Seppälä, Managing Director of the Finnish Water Utilities Association for his invaluable guidance. We also highly appreciate the contribution of the utility personnel participating in the survey.

\section{References}

[1] EPA (2010) EPA's Clean Water and Drinking Water Infrastructure. Sustainability Policy. 6 p.

https://www.epa.gov/sites/production/files/2016-01/documents/clean-water-and-dr inking-water-infrastructure-sustability-policy.pdf

[2] EPA (2017) Water Infrastructure Challenge. https://www.epa.gov/sustainable-water-infrastructure/water-infrastructure-challenge

[3] Finlex (2016) Water Services Act 119/2001 English (Amendments up to 979/2015 Included). http://www.finlex.fi/en/laki/kaannokset/2001/en20010119

[4] Ministry of Agriculture and Forestry, Finland, MFA (2015) The Guidelines for the Water Services Act, 50 p. (In Finnish)

http://www.mmm.fi/attachments/vesivarat/IJKgPV0P5/Vesihuoltolakiopas_2015.p df

[5] Association of Finnish Local and Regional Authorities (2007) The Municipalities and the Water Services in Tomorrow's Finland. The Position Paper, 35 p. (In Finnish)

http://www.kunnat.net/fi/asiantuntijapalvelut/yty/vesihuolto/Documents/Kunnat\% 20ja\%20vesihuolto\%20huomisen\%20Suomessa.pdf

[6] Pöyry Finland Oy (2013) Standardization of the Asset Valuation Principles for the Water Services Undertakings. 93 p. (In Finnish) http://www.vvy.fi/files/3483/Raportti_arvonmaaritys_26112013.pdf

[7] Luukkonen, H. (2103) The Water Associations, the Municipal Water Undertakings and the Municipalities. The Association of Finnish Local and Regional Authorities, 418 p. (In Finnish) http://shop.kunnat.net/product_details.php?p=2905 
[8] Ministry of Agriculture and Forestry, Finland, MFA (2013) The Production of Water Services Must Be Secured in All Circumstances. (In Finnish) http://www.mmm.fi/fi/index/etusivu/vesivarat/vesihuolto.html

[9] Heino, O.A., Takala, A.J. and Katko, T.S. (2011) Challenges to Finnish Water and Wastewater Services in the Next 20 - 30 Years. E-Water. Official Publication of the European Water Association (EWA), 1-20.

http://www.ewa-online.eu/portale/ewa/ewa.nsf/C125723B0047EC38/60CAFA191D 51F6CDC1257876002699C6/\$FILE/Challenges_A_TAKALA_OH_Final.pdf

[10] Silfverberg, P. (2016) The Future Challenges of Water Services. Seminar Report 11 August 2016, 49 p. (In Finnish)

[11] Finnish Association of Civil Engineers, RIL (2017) The State of the Built Environment-ROTI 2017. 84 p. (In Finnish) http://roti.fi/taustat/materiaalipankki/

[12] Water Services Association of Australia, WSAA (2015) Project Factsheet: ISO 55001 Guidelines for the Water Industry.

https://www.wsaa.asn.au/publication/project-factsheet-iso-55001-guidelines-water-i ndustry

[13] Vinnari, E.M. (2006) Water Utility Asset Management-Lessons from the US. Periodical Vesitalous 6/2006. Finnish Journal for Professionals in the Water Sector, 33-36. (In Finnish)

http://www.vesitalous.fi/wp-content/uploads/2013/07/Vesitalous_6_2006.pdf

[14] Finnish Water Utilities Association, FIWA (2001) Guidelines and Recommendations for the Charges of the Water Utilities. (In Finnish)

[15] Vaattovaara, M. and Sipilä, O. (2005) The Background Paper for the Physical Asset Management. Tekes Review 170/2005. Tekes-The Finnish Funding Agency for Innovation, 68 p. (In Finnish) https://www.tekes.fi/globalassets/julkaisut/fyysisen.pdf

[16] Vinnari, E.M. and Hukka, J.J. (2010) An International Comparison of the Institutional Governance of Water Utility Asset Management and Its Implications for Finland. Water Policy, 12, 52-69. https://doi.org/10.2166/wp.2009.115

[17] Gustafsson, J. (2013) The Cost Recovery and Pricing of Water Services. 114 p. (In Finnish)

http://www.vvy.fi/files/3484/Laitosmuotoisten_vesihuoltopalvelujen_kustannusten kattaminen_ja_hinnoittelu.pdf

[18] Alatyppö, V. and Paavilainen, J., Eds. (2016) The Asset Management for the Municipal Infrastructure: A Quick Guide. Municipal Engineering Association of Finland, SKTY, 54 p. (In Finnish) https://www.tiedekirja.fi/default/kuntainfran-omaisuudenhallinta-pikaopas.html

[19] Institute of Public Works Engineering Australasia, IPWEA (2015) The International Infrastructure Management Manual (IIMM).

http://www.ipwea.org/publications/bookshop/ipweabookshop/iimm 